\title{
MOLECULAR DETECTION OF HEMOPLASMA INFECTION AMONG CATS FROM SÃO LUÍS ISLAND, MARANHÃO, BRAZIL
}

\author{
Braga, M.S.C.O. ${ }^{1,2}$; André, M.R. ${ }^{1}$; Freschi, C.R. ${ }^{1}$; Teixeira, M.C.A. ${ }^{1}$; Machado, R.Z. ${ }^{\text {* }}$ \\ ${ }^{1}$ Universidade Estadual Paulista, Jaboticabal, SP, Brasil; ${ }^{2}$ Universidade Estadual do Maranhão, São Luís, MA, Brasil.
}

Submitted: March 21, 2011; Returned to authors for corrections: August 26, 2011; Approved: January 16, 2012.

\begin{abstract}
Hemoplasmas are bacteria that infect erythrocytes, attaching to the red blood cell. There is a need for more reports of hemoplasma infection prevalence and molecular characterization among cats in Brazil since there are only few published reports. The present work aimed to detect and molecularly characterize the presence of hemotrophic mycoplasmas in domestic cats with outdoor access from São Luís, Maranhão, Brazil. Twenty cats (10\%) were positive for Candidatus M. haemominutum, five (2.5\%) for M. haemofelis, and four (2.\%) for M. turicensis based on 16S rRNA gene PCRs. Five cats $(2.5 \%)$ were co-positive for Candidatus M. haemominutum and M. haemofelis. PCR diagnosis was confirmed by sequencing; and phylogenetic analysis was based on 16S rRNA and rnpb genes.
\end{abstract}

Key words: cats, Mycoplasma haemofelis, Candidatus Mycoplasma haemominutum, Candidatus Mycoplasma turicensis

\section{INTRODUCTION}

The hemotropic mycoplasmas (hemoplasmas) are bacteria of small size and genomes, fastidious growth requirements, that lacks cell wall, and infect erythrocytes, attaching to the red blood cytoplasmic membrane (37). Cats can be infected by a range of hemoplasmas: Mycoplasma haemofelis, Candidatus Mycoplasma haemominutum, M. turicensis and Candidatus $\mathrm{M}$. haematoparvum. Mycoplasma haemofelis is often associated with haemolytic anaemia during acute infection; and infection by Candidatus M. haemominutum and Candidatus $\mathrm{M}$. turicensis may result in a fall in erythrocytic parameters, but anaemia is not normally found unless concurrent disease is present (37). Common signs exhibited by acutely ill cats include pallor, lethargy, anorexia, weigh loss, depression, dehydration, and intermittent pyrexia (37).

Recently, M. haemofelis was detected using PCR in a human immunodeficiency virus-infected human from Brazil that was co-infected with $B$. henselae, suggesting that infection by M. haemofelis may be a zoonosis (9).

There are only few reports of hemoplasma infection prevalence among cats in Brazil $(27,33)$. Besides, molecular characterization of hemoplasmas in domestic cats from Brazil has not been conducted yet, to our knowledge. The present work aimed to detect and molecularly characterize the presence of hemotrophic mycoplasmas in domestic cats from São Luís,

*Corresponding Author. Mailing address: Laboratório de Imunoparasitologia, Departamento de Patologia Veterinária, Faculdade de Ciências Agrárias e Veterinárias Júlio de Mesquita Filho (UNESP), Campus de Jaboticabal, Via de Acesso Prof. Paulo Donato Castellane, s/n, Zona Rural, CEP: 14884-900, Jaboticabal, São Paulo, Brazil.; Tel.: +55 (16) 3203-2663 Fax: +55 (16) 3202-4275.; E-mail: zacarias@fcav.unesp.br 
Maranhão, Brazil.

\section{MATERIALS AND METHODS}

Between October 2008 and January 2009, whole blood samples were collected from 200 domestic cats with outdoor access from São Luís, Maranhão, Brazil. All animals were clinically healthy at the time of samples collection. The blood samples were collected in EDTA and stored at $-20^{\circ} \mathrm{C}$ until DNA extraction.

DNA was extracted from $200 \mu \mathrm{L}$ of whole blood using the QIAamp DNA Blood Mini kit (QIAGEN®, Valencia, California, USA) according to the manufacturer's instructions.

To amplify a $393 \mathrm{pb}$ partial sequence of M. haemofelis 16S rRNA gene, the PCR was performed with $5 \mu \mathrm{L}$ of template DNA in $25 \mu \mathrm{L}$ reaction mixtures containing 10X PCR buffer, $1.0 \mathrm{mM} \mathrm{MgCl}$, 0,2 mM deoxynucleotide triphosphate (dNTPs) mixture, 1.5 U Taq DNA Polymerase (Invitrogen, Carlsbad, California, USA) and $0.2 \mathrm{mM}$ of primers (H. felis-F1 - 5' - GA CTTTGGTTTCGGCCAAGG-3'; H. felisR3 -5'- CGAAGTAC TATCATAATTAT CCCTC- 3') described elsewhere (3). The cycling conditions consisted of an initial denaturation of 10 $\min$ at $94^{\circ} \mathrm{C}$ for $45 \mathrm{~s}, 54{ }^{\circ} \mathrm{C}$ for $45 \mathrm{~s}, 72^{\circ} \mathrm{C}$ for $1 \mathrm{~min}$ and a final elongation step for $7 \mathrm{~min}$. For Candidatus M. haemominutum, the PCR was performed using the primers $1183 \mathrm{~F}$ (5'GCATAATGTGTCGCAATC-3') and 1290R (5'- GTTTCAA CTAGTACTTTCTCC C-3') that amplify a 130bp of $16 \mathrm{~S}$ rRNA gene (12). The cycling conditions consisted an initial denaturation of $4 \mathrm{~min}$ at $94^{\circ} \mathrm{C}$, followed by 35 cycles of $94^{\circ} \mathrm{C}$ for $30 \mathrm{~s}, 53^{\circ} \mathrm{C}$ for $1 \mathrm{~min}, 72{ }^{\circ} \mathrm{C}$ for $45 \mathrm{~s}$ and a final elongation step for $5 \mathrm{~min}$. Positive samples were submitted to a PCR that amplify a $1457 \mathrm{bp}$ fragment of the 16S rRNA gene using primers $8 \mathrm{~F}$ (5'-AGAGTTTGATCCTGGCTCAG-3') and 1492R (5'-GGTTACCTTGTTACGACTT -3') (30), which amplify almost the complete length of the 16S rRNA gene. Cycling conditions were as follows: $95^{\circ} \mathrm{C}$ for $10 \mathrm{~min}$, followed by 35 cycles of amplification $\left(1 \mathrm{~min}\right.$ at $95^{\circ} \mathrm{C}, 1 \mathrm{~min}$ at $48^{\circ} \mathrm{C}$ and
2 min at $72^{\circ} \mathrm{C}$ ), and a final extension of $5 \min$ at $72^{\circ} \mathrm{C}$.

For Candidatus M. turicensis, the PCR was performed using the primers Mt1Fw (5'-GTATCCTCCATCAGACAGA A-3') and Mt2Rv-(5'-CGCTCCATATTTAATTCCAA-3') that amplify a $488 \mathrm{pb}$ fragment of $16 \mathrm{~S}$ rRNA (33). The cycling conditions consisted an initial denaturation of $2 \mathrm{~min}$ at $95^{\circ} \mathrm{C}$, followed by 35 cycles of $94^{\circ} \mathrm{C}$ for $1 \mathrm{~min}, 55^{\circ} \mathrm{C}$ for $45 \mathrm{~s}, 72{ }^{\circ} \mathrm{C}$ for $45 \mathrm{~s}$ and a final elongation step for $5 \mathrm{~min}$. Fragments of expected size from $M$. haemofelis, Candidatus $\mathrm{M}$. haemominutum and Candidatus $\mathrm{M}$. turicensis cloned into pGEM T-Easy Vector System II (Promega, Madison, Wisconsin, USA) were used as positive controls. Ultra-pure sterile water was used as negative control.

Samples that were posiive to the above described PCRs were submitted to a PCR based on RNAase P gene (rnpb), using the primers 80F1 (5'-GAGGAAAGTCCRYGCTW GCAC-3') and 290R1 (5'-TCCCYTACCRAAATTTRGGTTT CT-3) (5). The cycling conditions consisted an initial denaturation of $5 \mathrm{~min}$ at $95^{\circ} \mathrm{C}$, followed by 45 cycles of $95^{\circ} \mathrm{C}$ for $1 \mathrm{~min}, 45^{\circ} \mathrm{C}$ for $1 \mathrm{~min}, 72{ }^{\circ} \mathrm{C}$ for $1 \mathrm{~min}$ and a final elongation step for $5 \mathrm{~min}$.

The reaction products were purified using Silica Bead DNA Gel Extraction Kit (Fermentas, São Paulo, SP, Brazil). Purified amplified DNA fragments from positive samples were subjected to sequencing for confirmation in an automatic sequencer (ABI Prism 310 Genetic Analyser - Applied Byosystem/ Perkin Elmer) and used for subsequent phylogenetic analysis. Phylogenetic reconstructions were based upon desoxiribonucleic acid sequences. Consensus sequences were obtained through the analysis of the products from sequencing from both forward and reverse oligonucleotides using the CAP3 program (http://mobyle.pasteur.fr/cgibin/MobylePortal/portal.py). Comparisons with sequences deposited in GenBank were done using the basic local alignment search tool $\left(\right.$ BLAST $\left.^{\circledR}\right)$. The CLUSTAL W (40) and MEGA (21) programs were used for alignment and phylogenetic analysis, respectively. The distance neighbor- 
joining method was used to build the phylogenetic tree (32) using the Kimura-2-parameter model. The bootstrap test with 1000 replications was replied to estimate the confidence of branching patterns of the neighbor-joining tree (11).

\section{RESULTS}

Twenty cats $(10 \%)$ were positive for Candidatus $\mathrm{M}$. haemominutum, five $(2.5 \%)$ for M. haemofelis, and four (2.\%) for $M$. turicensis based on $16 \mathrm{~S}$ rRNA PCRs. Five cats $(2.5 \%)$ were co-positive for Candidatus M. haemominutum and $M$. haemofelis. Positive cats to Candidatus M. turicensis based on 16S rRNA were not positive at PCR based on rnpb gene. The sequencing based on $16 \mathrm{~S}$ rRNA and rnpb genes confirmed that the sampled cats were parasitized by $M$. haemofelis, Candidatus M. haemominutum and Candidatus M. turicensis (Table 1; Figures 1 and 2).

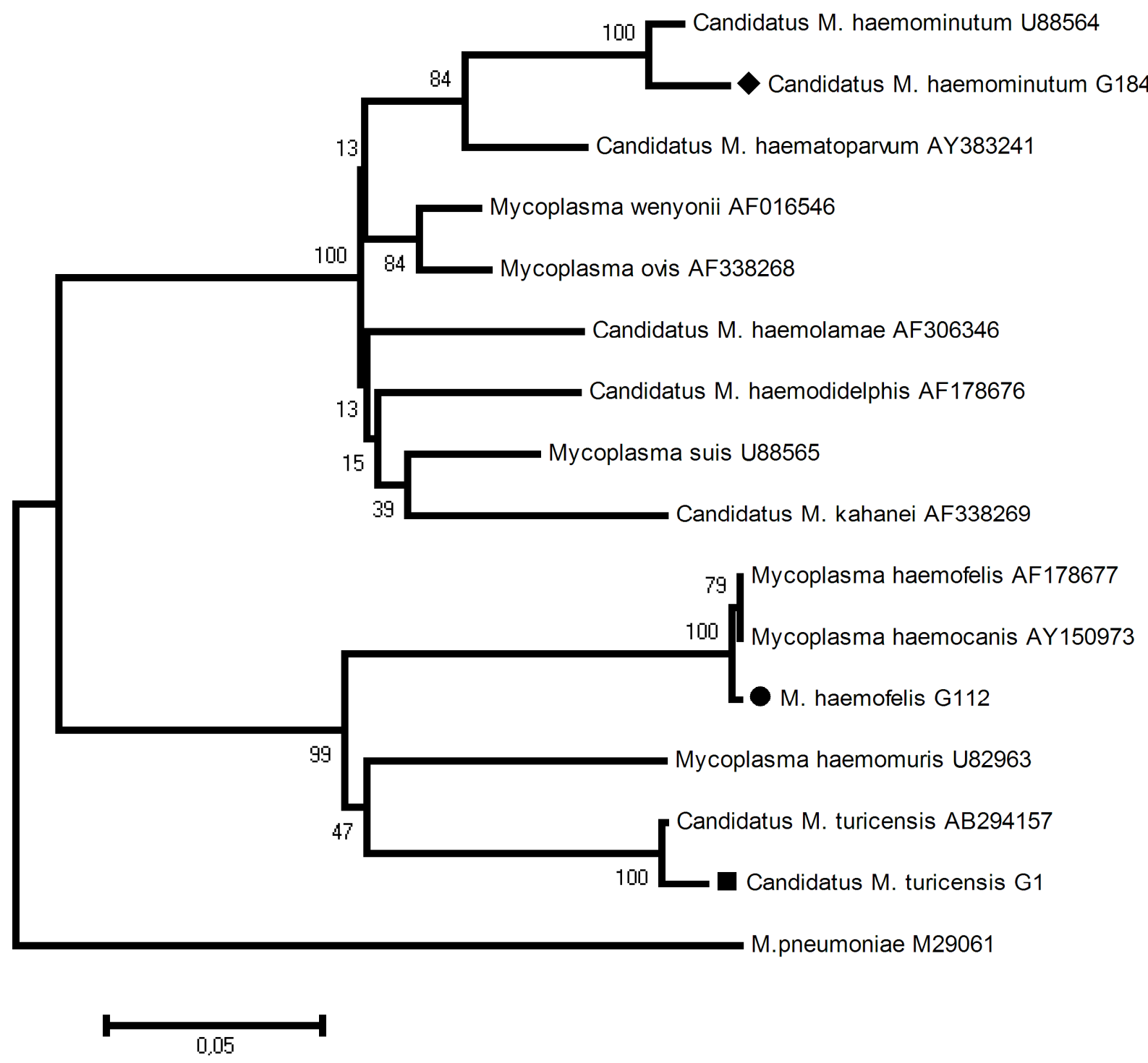

Figure 1. Neighbor-joining Kimura 2-parameters method based phylogenetic position of Mycoplasma spp. 16 rRNA gene from cats. 


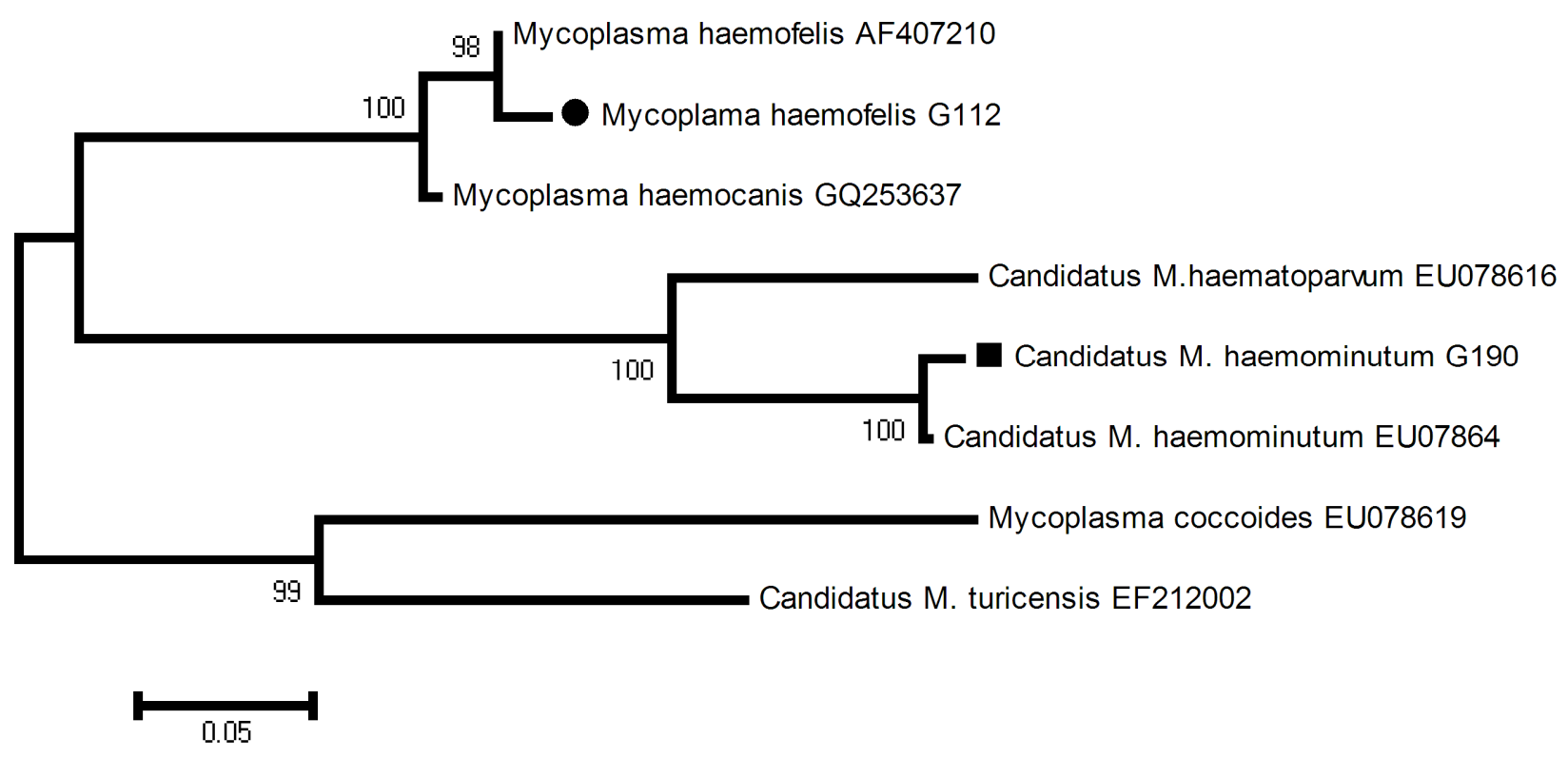

Figure 2. Neighbor-joining Kimura 2-parameters method based phylogenetic position of Mycoplasma spp. rnpb gene from cats.

Table 1. Closest Genbank entry for the consensus sequence of 16S RNA and rnpb genes from hemoplasmas in cats from São Luis, Maranhão, Brazil

\begin{tabular}{|c|c|c|c|}
\hline Hemoplasmas & $\begin{array}{c}\text { Number of } \\
\text { positive animals }\end{array}$ & $\begin{array}{c}\text { Closest Genbank entry (by BLAST®) } \\
\% \text { sim. - 16S rRNA gene } \\
\end{array}$ & $\begin{array}{l}\text { Closest Genbank entry (by BLAST®) } \\
\text { \% sim. - rnpb gene } \\
\end{array}$ \\
\hline $\begin{array}{l}\text { Mycoplasma } \\
\text { haemofelis }\end{array}$ & 5 & $\begin{array}{c}\text { Mycoplasma haemofelis - AF178677 - } \\
99 \%\end{array}$ & $\begin{array}{c}\text { Mycoplasma haemofelis - AF407210 - } \\
99 \%\end{array}$ \\
\hline $\begin{array}{c}\text { Candidatus } \\
\text { Mycoplasma } \\
\text { haemominutum }\end{array}$ & 20 & $\begin{array}{l}\text { Candidatus } \mathrm{M} \text {. haemominutum - } \\
\text { EU839983 - 99\% }\end{array}$ & $\begin{array}{c}\text { Candidatus M. haemominutum - } \\
\text { EU078614 - 98\% }\end{array}$ \\
\hline $\begin{array}{c}\text { Candidatus } \\
\text { Mycoplasma } \\
\text { turicensis }\end{array}$ & 4 & $\begin{array}{c}\text { Candidatus M. turicensis - EU839977 } \\
\qquad-99 \%\end{array}$ & - \\
\hline
\end{tabular}

\section{DISCUSSION}

The most prevalent hemoplasma found in the present study was Candidatus M. haemominutum. In the same way, in most of the prevalence studies around the world, Candidatus M. haemominutum has been the most common hemoplasma found, with lower prevalence of Candidatus M. turicensis and M. haemofelis detected (36). However, high prevalences of the latter two species have occasionally been reported, such as in a South African study with Candidatus M. turicensis (24), and in a Canadian study with M. haemofelis (18). The prevalence among domestic cats around the world ranged from $0.4 \%$ to $35 \%$ for Candidatus M. haemominutum, from $0.3 \%$ to $6.5 \%$ for Candidatus M. turicensis, from $0.125 \%$ to $10 \%$ to Mycoplasma haemofelis, and from 0 to $0.7 \%$ for Candidatus M. haematoparvum-like $(1,2,10,13,14,16,17,18,19,20,22$, $23,24,26,27,28,31,36,38,39,41,45)$.

Bloodsucking arthropods, such as ticks and fleas, are suspected to be involved in the transmission of feline hemoplasmas between domestic cats $(23,34)$, but an attempted 
experimental transmission between cats via fleas has not been conclusive (43). Ingestion of Mycoplasma-infectedCtenocephalides felis or by-products are not important means of transmission for $M$. haemofelis or Candidatus $\mathrm{M}$. haemominutum (44). The transmission of hemoplasmas by social contact seems less likely than transmission by aggressive interaction $(7,29)$.

Although hemoplasmas have been detected in cats from several regions of Brazil (4), few reports have been published yet. Until the present time, M. haemofelis and Candidatus M. haemominutum have been reported in cats from Paraná (8) and Rio de Janeiro states (27), and in wild felids maintained in captivity in São Paulo state (42). Candidatus Mycoplasma haemominutum DNA was detected in a lion from a zoo in Curitiba, Paraná state, Brazil (15). Candidatus M. turicensis have only been detected in cats from Rio Grande do Sul state (33) and wild felids maintained in captivity in São Paulo (42).

\section{CONCLUSION}

Using molecular tools, the present work showed that Mycoplasma haemofelis, Candidatus Mycoplasma haemominutum and Candidatus Mycoplasma turicensis circulate among cats in Maranhão state, Brazil. More studies concerning the genetic variability among hemoplasmas isolates infecting domestic and wild animals in Brazil and around the world should be done, aiming to verify the relationship among geographic distribution, genetic diversity and threat to animal and human healthy.

\section{ACKNOWLEDGEMENTS}

The authors would like to thank Conselho Nacional de Desenvolvimento Científico e Tecnológico ( $\mathrm{CNPq})$ for the financial support (number 479162/2007-7); Joanne Messick and Andrea Pires dos Santos from Purdue University, West Lafayette, USA, for supplying hemoplasma DNA positive controls.

\section{REFERENCES}

1. Barrs, V.R.; Beatty, J.A.; Wilson, B.J.; Evans, N.; Gowan, R.; Baral, R.M.; Lingard, A.E.; Perkovic, G.; Hawley, J.R.; Lappin, M.R. (2010). Prevalence of Bartonella species, Rickettsia felis, hemoplasmas and the Ehrlichia group in the blood of cats and fleas in eastern Australia. Aust. Vet. J. 88 (5), 160-5.

2. Bauer, N.; Balzer, H.J.; Thüre, S.; Moritz, A. (2008). Prevalence of feline hemotropic mycoplasmas in convenience samples of cats in Germany. J. Feline Med. Surg. 10 (3), 252-8.

3. Berent, L.M.; Messick, J.B.; Cooper, S.K. (1998). Detection of Haemobartonella felis in cats with experimentally induced acute and chronic infections, using a polymerase chain reaction assay. Am. J. Vet. Res. 59 (10), 1215-1220.

4. Biondo, A.W.; dos Santos, A.P.; Guimarães, A.M.S.; Vieira, R.F.C.; Vidotto, O.; Macieira, D.B.; Almosny, N.R.P.; Molento, M.P.; Timenetsky, J.; Morais, H.A.; González, F.H.D.; Messick, J.B. (2009). A review of the occurrence of hemoplasmas (hemotrophic mycoplasmas) in Brazil. Rev. Bras. Parasitol. Vet. 18(3), 1-7.

5. Birkenheuer, A.J.; Breitschwerdt, E.B.; Alleman, A.R.; Pitulle, C. (2002). Differentiation of Haemobartonella canis and Mycoplasma haemofelis on the basis of comparative analysis of gene sequences. Am. J. Vet. Res. 63 (10), 1385-1388.

6. Criado-Fornelio, A.; Martinez-Marcos, A.; Buling-Saraña, A.; BarbaCarretero, J.C. (2003). Prevalence of Mycoplasma haemofelis, Mycoplasma haemominutum and piroplasmids in cats from southern Europe: a molecular study. Vet. Microbiol. 93 (4), 307-317.

7. Dean, R.S.; Helps, C.R.; Jones, T.J.G.; Tasker, S. (2008). Use of realtime PCR to detect Mycoplasma haemofelis and Candidatus Mycoplasma haemominutum in the saliva and salivary glands of hemoplasma-infected cats. J. Feline Med. Surg. 10 (4), 413-417.

8. De Morais, H.A.; Guimarães, A.M.S.; Vidotto, O.; Baumann, A.; Biondo, A.W.; Messick, J.B. (2007). Co-infection with Mycoplasma haemofelis and Candidatus Mycoplasma haemominutum in three cats from Brazil. J. Feline Med. Surg. 9 (6), 518-520.

9. Dos Santos, A.P.; dos Santos, R.P.; Biondo, A.W.; Dora, J.M.; Goldani, L.Z.; de Oliveira, S.T.; Guimarães, A.M.S.; Timenetsky, J.; de Morais, H.A.; González, F.H.D.; Messick, J.B. (2008). Hemoplasma infection in HIV-positive patient, Brazil. Emerg. Infect. Dis. 14 (12), 1922-1924.

10. Eberhardt, J.M.; Neal, K.; Shackelford, T.; Lappin, M.R. (2006). Prevalence of selected infectious disease agents in cats from Arizona. $J$. Feline Med. Surg. 8 (3), 164-8.

11. Felsenstein, J. (1985). Confidence limits on phylogenies: an approach using the bootstrap. Evolution. 39, 783-791.

12. Foley, J.E.; Harrus, S.; Poland, A.; Chomel, B.; Pedersen, N.C. (1998). Molecular, clinical, and pathologic comparison of two distinct strains of 
Haemobartonella felis in domestic cats. Am J Vet Res. 59 (12), 1581 1588 .

13. Fujihara, M.; Watanabe, M.; Yamada, T.; Harasawa, R. (2007). Occurrence of Candidatus Mycoplasma turicensis infection in domestic cats in Japan. J. Vet. Med. Sci. 69 (10), 1061-1063.

14. Gentilini, F.; Novacco, M. Turba, M.E.; Willi, B.; Bacci, M.L.; Hofmann-Lehmann, R. (2009). Use of combined conventional and realtime PCR to determine the epidemiology of feline hemoplasma infections in northern Italy. J. Feline Med. Surg. 11 (4), 277-85.

15. Guimarães, A.M.S., Javarousky, M.L., Bonat, M., Lacerda, O., Balbinotti, B., Queiroz, L.G.P.B., Timenetsky, J., Biondo, A.W., Messick, J.B., 2007. Molecular detection of Candidatus Mycoplasma haemominutum in a lion (Panthera lion) from a Brazilian zoological garden. Rev. Inst. Med. Trop. S. Paulo 49, 195-196.

16. Ishak, A.M.; Radecki, S.; Lappin, M.R. (2007). Prevalence of Mycoplasma haemofelis, Candidatus Mycoplasma haemominutum, Bartonella species, Ehrlichia species, and Anaplasma phagocytophilum DNA in the blood of cats with anemia. J. Feline Med. Surg. 9 (1), 1-7.

17. Inokuma, H.; Taroura, S.; Okuda, M.; Hisasue, M.; Itamoto, K.; Une, S.; Nakaichi, M.; Taura Y. (2004). Molecular survey of Mycoplasma haemofelis and Candidatus Mycoplasma haemominutum infection in cats in Yamaguchi and surrounding areas. J. Vet. Med. Sci. 66 (8), $1017-$ 1020 .

18. Juvet, F.; Lappin, M.R.; Brennan, S.; Mooney, C.T. (2010). Prevalence of selected infectious agents in cats in Ireland. J. Feline Med. Surg. 12 (6), 476-482.

19. Kamrani, A.; Parreira, V.R.; Greenwood, J.; Prescott, J.F. (2008). The prevalence of Bartonella, hemoplasma, and Rickettsia felis infections in domestic cats and in cat fleas in Ontario. Can. J. Vet. Res. 72 (5), 411419.

20. Kewish, K.E.; Appleyard, G.D.; Myers, S.L.; Kidney, B.A.; Jackson, M.L. (2004). Mycoplasma haemofelis and Mycoplasma haemominutum detection by polymerase chain reaction in cats from Saskatchewan and Alberta. Can. Vet. J. 45 (9), 749-52.

21. Kumar, S.; Tamura, K.; Nei, M. (2004). MEGA 3: Integrated software for molecular evolutionary genetics analysis and sequence alignment. Brief. Bioinformat. 5 (2), 150-163.

22. Laberke, S.; Just, F.; Pfister, K.; Hartmann, K. (2010). Prevalence of feline hemoplasma infection in cats in Southern Bavaria, Germany, and infection risk factor analysis. Berl. Munch. Tierarztl. Wochenschr. 123 (1-2), 42-8.

23. Lappin, M.R.; Griffin, B.; Brunt, J.; Riley, A.; Burney, D.; Hawley, J.; Brewer, M.M.; Jensen, W.A. (2006). Prevalence of Bartonella species, hemoplasma species, Ehrlichia species, Anaplasma phagocytophilum, and Neorickettsia risticii DNA in the blood of cats and their fleas in the United States. J. Feline Med. Surg. 8 (2), 85-90.
24. Levy, J.K.; Crawford, P.C.; Lappin, M.R.; Dubovi, E.J.; Levy, M.G.; Alleman, R.; Tucker, S.J.; Clifford, E.L. (2008). Infectious diseases of dogs and cats on Isabela Island, Galapagos. J. Vet. Intern. Med. 22 (1),60-65

25. Lobetti, R.G.; Tasker, S. (2004). Diagnosis of feline hemoplasma infection using a real-time PCR assay. J. S. Afr. Vet. Assoc. 75 (2), 9499.

26. Luria, B.J.; Levy, J.K.; Lappin, M.R.; Breitschwerdt, E.B.; Legendre, A.M.; Hernandez, J.A.; Gorman, S.P.; Lee, I.T. (2004). Prevalence of infectious diseases in feral cats in Northern Florida. J. Feline Med. Surg. $6(5), 287-96$

27. Macieira, D.B.; de Menezes, R.C.A.A.; Damico, C.B.; Almosny, N.R.P.; McLane, H.L.; Daggy, J.K.; Messick, J. B. (2008). Prevalence and risk factors for hemoplasmas in domestic cats naturally infected with feline immunodeficiency virus and/or feline leukemia virus in Rio de Janeiro, Brazil. J. Feline Med. Surg. 10 (2), 120-129.

28. Maher, I.E.; Tasker, S.; Polizopoulou, Z.; Dasopoulou, A.; Egan, K.; Helps, C.R.; Papasouliotis, K. (2010). Polymerase chain reaction survey of feline hemoplasma infections in Greece. J. Feline Med. Surg. 12 (8), 601-605.

29. Museux, K.; Boretti, F.S.; Willi, B., Riond; B., Hoelzle; K., Hoelzle, L.E.; Wittenbrink, M.M.; Tasker, S.; Wengi, N.; Reusch, C.E.; Lutz, H.; Hofmann-Lehmann, R. (2009). In vivo transmission studies of Candidatus Mycoplasma turicensis in the domestic cat. Vet. Res. 40 (5), 45.

30. Pitulle, C.; Citron, D.M.; Bochner, B.; Barbers, R.; Appleman, M.D. (1999). Novel bacterium isolated from a lung transplant patient with cystic fibrosis. J. Clin. Microbiol. 37 (12), 3851-3855.

31. Roura, X.; Peters, I.R.; Altet, L.; Tabar, M.D.; Barker, E.N.; Planellas, M.; Helps, C.R.; Francino, O.; Shaw, S.E.; Tasker, S. (2010). Prevalence of hemotropic mycoplasmas in healthy and unhealthy cats and dogs in Spain. J. Vet. Diagn. Invest. 22 (2), 270-4.

32. Saitou, N.; Nei, M. (1987). The neighbor-joining method: a new method for reconstructing phylogenetic trees. Mol. Biol. Evol. 44 (4), 406-425.

33. Santos, A.P.; Messick, J.B.; Biondo, A.W.; Oliveira, S.T.; Pedralli, V.; Lasta, C.S.; Lacerda, L.A.; Esteves, V.S.; Hofmann-Lehmann, R.; Willi, B.; González, F.H. (2009). Design, optimization, and application of a conventional PCR assay with an internal control for detection of Candidatus Mycoplasma turicensis 16S rDNA in domestic cats from Brazil. Vet. Clin. Pathol. 38 (4), 443-452.

34. Shaw, S. E.; Kenny, M.J.; Tasker, S.; Birtles, R.J. (2004). Pathogen carriage by the cat flea Ctenocephalides felis (Bouché) in the United Kingdom. Vet. Microbiol. 102 (3-4), 183-188.

35. Sykes, J.E.; Drazenovich, N.L.; Ball, L.M.; Leutenegger, C.M. 2007. Use of conventional and real-time polymerase chain reaction to determine the epidemiology of hemoplasma infections in anemic and nonanemic cats. 
J. Vet. Intern. Med. 21(4), 685-93.

36. Sykes, J.E.; Terry, J.C.; Lindsay, L.L.; Owens, S.D. (2007). Prevalences of various hemoplasma species among cats in the United States with possible hemoplasmosis. J. Am. Vet. Med. Assoc. 232 (3), 372-9.

37. Tasker, S. Hemotropic mycoplasmas: what's their real significance in cats? (2010). J. Feline Med. Surg 12 (5), 369-381.

38. Tasker, S.; Binns, S.H.; Day, M.J.; Gruffydd-Jones, T.J.; Harbour, D.A.; Helps, C.R.; Jensen, W.A.; Olver, C.S.; Lappin, M.R. (2003). Use of a PCR assay to assess the prevalence and risk factors for Mycoplasma haemofelis and Candidatus Mycoplasma haemominutum in cats in the United Kingdom. Vet Rec. 152 (7), 193-198.

39. Tasker, S.; Braddock, J.A.; Baral, R.; Helps, C.R.; Day, M.J.; GruffyddJones, T.J.; Malik, R. (2004). Diagnosis of feline hemoplasma infection in Australian cats using a real-time PCR assay. J. Feline Med. Surg. 6 (6), 345-54

40. Thompson, J.D.; Higgins, D.G.; Gibson, T.J. (1994). CLUSTAL W: improving the sensitivity of progressive multiple sequence alignment through sequence weighting, position specific gap penalties and weight matrix choice. Acids. Res. 22 (22), 1673-4680.

41. Willi, B.; Boretti, F.S.; Baumgartner, C.; Tasker, S.; Wenger, B.; Cattori,
V.; Meli, M.L.; Reusch, C.E.; Lutz, H.; Hofmann-Lehmann, R. (2006). Prevalence, risk factor analysis, and follow-up of infections caused by three feline hemoplasma species in cats in Switzerland. J. Clin. Microbiol. 44 (3), 961-969.

42. Willi, B.; Filoni, C.; Catão-Dias, J.L.; Cattori, V.; Meli, M.L.; Vargas, A.; Martínez, F.; Roelke, M.E.; Ryser-Degiorgis, M.P.; Leutenegger, C.M.; Lutz, H.; Hofmann-Lehmann, R. (2007). Worldwide occurrence of feline hemoplasma infections in wild felid species. J. Clin. Microbiol. 45 (4), 1159-1166.

43. Woods, J.E.; Brewer, M.M.; Hawley, J.R.; Wisnewski, N.; Lappin, M.R. (2005). Evaluation of experimental transmission of Candidatus Mycoplasma haemominutum and Mycoplasma haemofelis by Ctenocephalides felis to cats. Am. J. Vet. Res. 66 (6), 1008-1012.

44. Woods, J.E.; Wisnewski, N.; Lappin, M.R. (2006). Attempted transmission of Candidatus Mycoplasma haemominutum and Mycoplasma haemofelis by feeding cats infected Ctenocephalides felis. Am. J. Vet. Res. 67 (3), 494-497.

45. Yu, D.H.; Kim, H.W.; Desai, A.R.; Han, I.A.; Li, Y.H.; Lee, M.J.; Kim, I.S.; Chae, J.S.; Park, J. (2007). Molecular detection of feline hemoplasmas in feral cats in Korea. J. Vet. Med. Sci. 69 (12), 1299-301. 